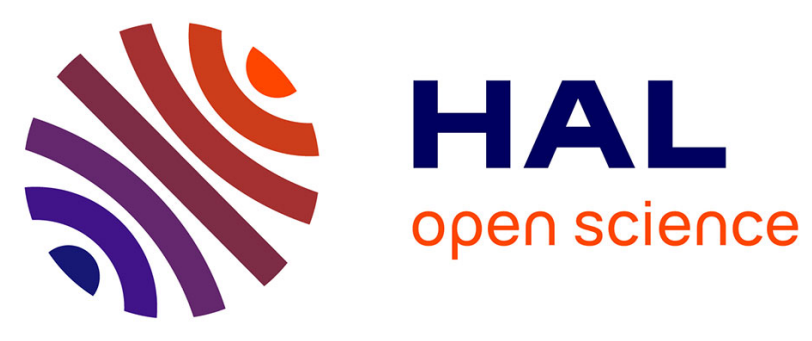

\title{
Ionic Complexes of Tetra- and Nonanuclear Cage Copper(II) Phenylsilsesquioxanes: Synthesis and High Activity in Oxidative Catalysis
}

Alexey Bilyachenko, Alena Kulakova, Mikhail Levitsky, Alexander Korlyukov, Victor N. Khrustalev, Anna Vologzhanina, Aleksei Titov, Pavel V. Dorovatovskii, Lidia Shul'Pina, Frédéric Lamaty, et al.

\section{To cite this version:}

Alexey Bilyachenko, Alena Kulakova, Mikhail Levitsky, Alexander Korlyukov, Victor N. Khrustalev, et al.. Ionic Complexes of Tetra- and Nonanuclear Cage Copper(II) Phenylsilsesquioxanes: Synthesis and High Activity in Oxidative Catalysis. ChemCatChem, 2017, 9 (23), pp.4437-4447. 10.1002/cctc.201701063 . hal-02385276

\section{HAL Id: hal-02385276 https://hal.science/hal-02385276}

Submitted on 4 Jan 2021

HAL is a multi-disciplinary open access archive for the deposit and dissemination of scientific research documents, whether they are published or not. The documents may come from teaching and research institutions in France or abroad, or from public or private research centers.
L'archive ouverte pluridisciplinaire HAL, est destinée au dépôt et à la diffusion de documents scientifiques de niveau recherche, publiés ou non, émanant des établissements d'enseignement et de recherche français ou étrangers, des laboratoires publics ou privés. 


\title{
Ionic Complexes of Tetra- and Nonanuclear Cage Copper(II) Phenylsilsesquioxanes: Synthesis and High Activity in Oxidative Catalysis
}

\author{
Alexey $\mid$ N. Bilyachenko, ${ }^{*[a, b]}$ Alena N. Kulakova, ${ }^{[a, b]}$ Mikhail M. Levitsky, ${ }^{[a]}$ \\ Alexander A. Korlyukov, ${ }_{1}^{[a, c]}$ Victor N. Khrustalev, ${ }_{1}^{[b]}$ Anna V. Vologzhanina, ${ }^{[a]}$ Aleksei A. Titov, ${ }^{[a, b]}$ \\ Pavel V. Dorovatovskii, ${ }^{[\mathrm{d}]}$ [idia|S. Shul'pina, ${ }^{[\mathrm{a}]}$ Frédéric Lamaty $^{*[\mathrm{e}]}$ Xavier Bantreil, ${ }^{[\mathrm{e}]}$ \\ Benoît Villemejeanne, ${ }^{[\mathrm{e}]}$ Cindy Ruiz, ${ }^{[\mathrm{e}]}$ Jean Martinez, ${ }^{[\mathrm{e}]}$ Elena S. Shubina, ${ }^{[\mathrm{la}}$ and \\ Georgiy B. Shul'pin* *f, g]
}

\begin{abstract}
Herein, we describe an approach to cage metallasilsesquioxanes by self-assembly with 1,2-bis(diphenylphosphino)ethane as a key reactant. This approach allowed us to achieve a unique family of complexes that includes anionic tetra- and nonanuclear cage copper(II) sodium silsesquioxane and cationic copper(I) 1,2-bis(diphenylphosphino)ethane components. Additional representatives of this intriguing metallasilsesquioxane family $\left(\mathrm{Cu}_{9} \mathrm{Na}_{6}\right.$ and $\left.\mathrm{Cu}_{9} \mathrm{Na}_{3} \mathrm{Cs}_{3}\right)$ were obtained through the
\end{abstract}

replacement of the original ethanol-based reaction medium by DMSO. The fascinating structural peculiarities of all products were established by using XRD and topological studies. Initial tests for the application of the synthesized complexes as catalysts revealed their very high activity in the homogeneous oxidation of alkanes and alcohols to produce alkyl hydroperoxides, ketones, and amides.

\section{Introduction}

Among the huge variety of 3D polycyclic (cage) metal-containing complexes, ${ }^{[1]}$ those based on structural silsesquioxane $\left(\mathrm{RSiO}_{1.5}\right)$ fragments ${ }^{[2]}$ attract special attention as systems that simulate metal-center-grafting to silica surfaces ${ }^{[3]}$ perfectly in heterogeneous catalytic applications. ${ }^{[4]}$ Such compounds (cage-like metallasilsesquioxanes, CLMSs) are also (i) active in homogeneous catalysis, ${ }^{[5]}$ (ii) demonstrate specific (spin glass) magnetic properties, ${ }^{[6]}$ or (iii) provide opportunities for unusual reactivity ${ }^{[7]}$ and structural reorganization governed by thermal treatment. ${ }^{[5 a, 8]}$ The most demanded synthetic approaches to CLMSs include reactions using cubane, ${ }^{[9]}$ cyclic, $^{[10]}$ and trisilanol $^{[2,11]}$ synthons as well as self-assembly ${ }^{[11 b, 12]}$ or transmetalation $^{[11 b, 13]}$ procedures. Here we report the preparation of new types of CLMSs following the "double ligation principle" of self-assembly. This new synthesis method implies the use of two types or reactants that are able to ligate metal ions in the process of cage assembly: an O-ligand (silsesquioxane) and a P-ligand (1,2-bis(diphenylphosphino)ethane; dppe). It is important to differentiate this approach from several syntheses of CLMSs that involve bidentate phosphine, in which phosphine served as a component of the initial metal complex. ${ }^{[14]}$ Here we show the possibility of a double $(\mathrm{O}, \mathrm{P})$ ligation approach to CLMSs, as well as the tendencies of the supramolecular aggregation of products and their catalytic properties in the oxidation of $\mathrm{C}-\mathrm{H}$ compounds and formation of amides. [a] Dr. A. N. Bilyachenko, A. N. Kulakova, Dr. M. M. Levitsky, Prof. A. A. Korlyukov, Dr. A. V. Vologzhanina, Dr. A. A. Titov, L. S. Shul'pina, Prof. E. S. Shubina

A. N. Nesmeyanov Institute of Organoelement Compounds Russian Academy of Sciences

Vavilov str. 28, 119991 Moscow (Russia)

E-mail:bilyachenko@ineos.ac.ru

[b] Dr. A. N. Bilyachenko, A. N. Kulakova, Prof. V. N. Khrustalev, Dr. A. A. Titov Peoples' Friendship University of Russia (RUDN University) Miklukho-Maklay Str. 6, 117198 Moscow (Russia)

[c] Prof. A. A. Korlyukov

Pirogov Russian National Research Medical University

Ostrovitianov str. 1, 117997Moscow (Russia)

[d] P. V. Dorovatovskii

National Research Center "Kurchatov Institute"

Akademika Kurchatova pl. 1, 123098Moscow (Russia) [e] Dr. F. Lamaty, Dr. X. Bantreil, B. Villemejeanne, C. Ruiz, Prof. J. Martinez Institut des Biomolécules Max Mousseron (IBMM) UMR 5247, CNRS, Université de Montpellier ENSCM, Site Triolet, Place Eugène Bataillon, 34095 Montpellier cedex 5 (France)

E-mail:frederic.lamaty@umontpellier.fr

[f] Prof. G. B. Shul'pin

Semenov Institute of Chemical Physics Russian Academy of Sciences Ulitsa Kosygina 4, Moscow 119991 (Russia) E-mail:shulpin@chph.ras.ru

[g] Prof. G. B. Shul'pin

Plekhanov Russian University of Economics

Stremyannyi pereulok 36, Moscow 117997 (Russia) 


\section{Results and Discussion}

\section{Synthesis}

To date, several instances of the use of phenyltrialkoxysilanes as simple but efficient educts in the self-assembly of CLMSs have been reported. ${ }^{[11 b, 12-13]}$ However, no examples of the involvement of the bidentate P-based ligand were among them. As we are interested in the principles of double-ligated (silsesquioxane/phosphine) CLMSs formation, we have performed several parallel reactions of the synthesis of $\mathrm{Cu}$-containing CLMSs. A three-component mixture was used for this self-assembly reaction: (i) highly reactive phenylsiloxanolate $\left[\left(\mathrm{PhSiO}_{1.5}\right)\left(\mathrm{NaO}_{0.5}\right)\right]_{n}$ moieties (prepared in situ from $\mathrm{PhSi}(\mathrm{OEt})_{3}$ and $\mathrm{NaOH}$ ) as the silsesquioxane component, (ii) 1,2-bis(diphenylphosphino)ethane as the phosphine component, and (iii) $\mathrm{CuCl}_{2}$ as a source of transition metal ions. Among the combinations of solvents used for the synthesis (DMF, acetonitrile,
THF, 1,4-dioxane, etc.), only ethanol was able to assist the assembly of the target complex (Scheme 1).

Two types of compounds could be isolated this way, depending on the $\mathrm{NaOH}$ loading (1 and 2; Figure 1). Com-

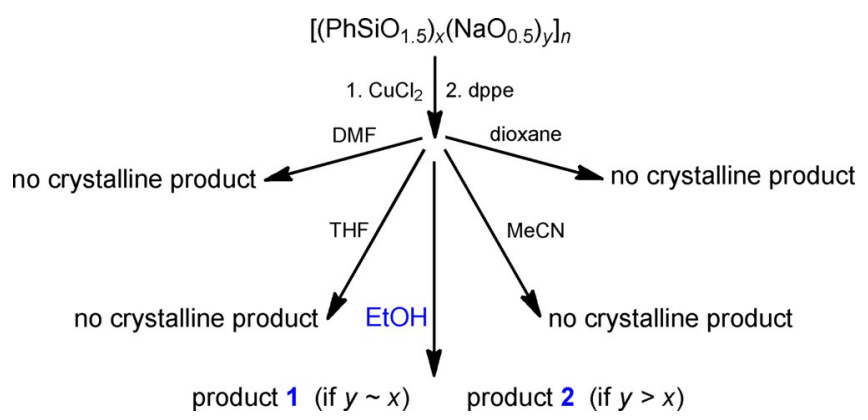

Scheme 1. Solvent variation during the synthesis of $\mathrm{Cu}, \mathrm{Na}$-phenylsilsesquioxanes. The use of EtOH provided 1 (42\%) and 2 (17\%).
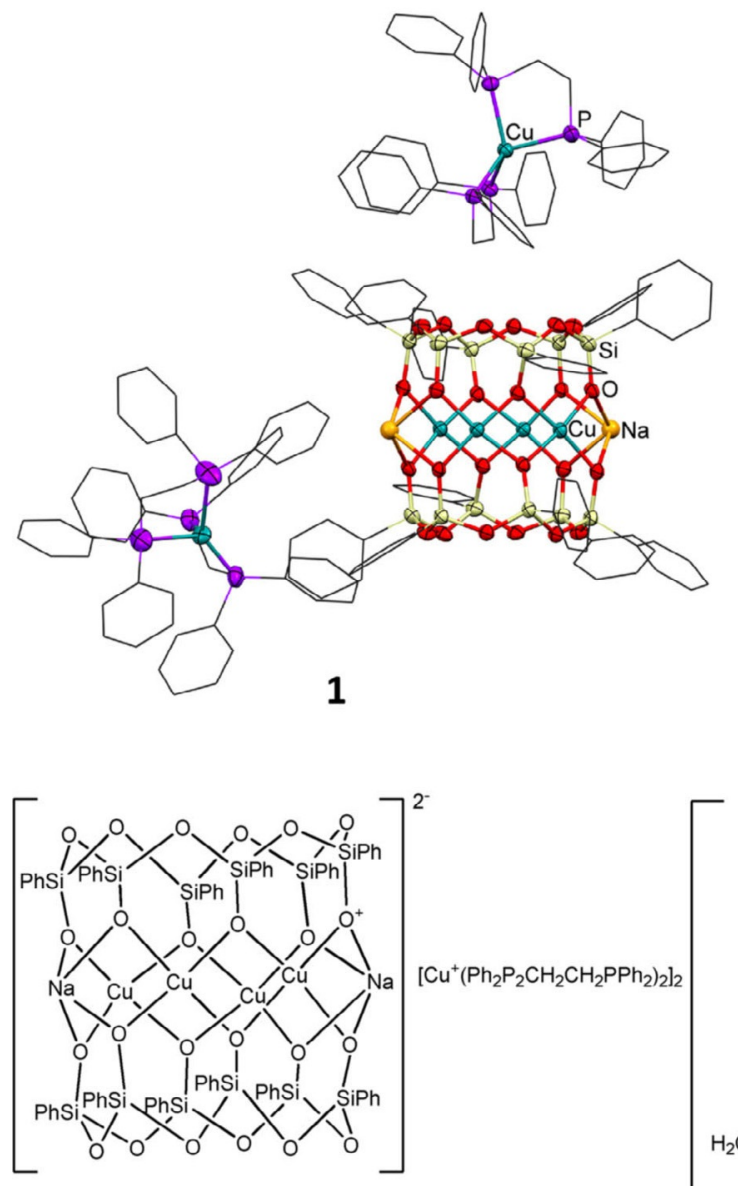

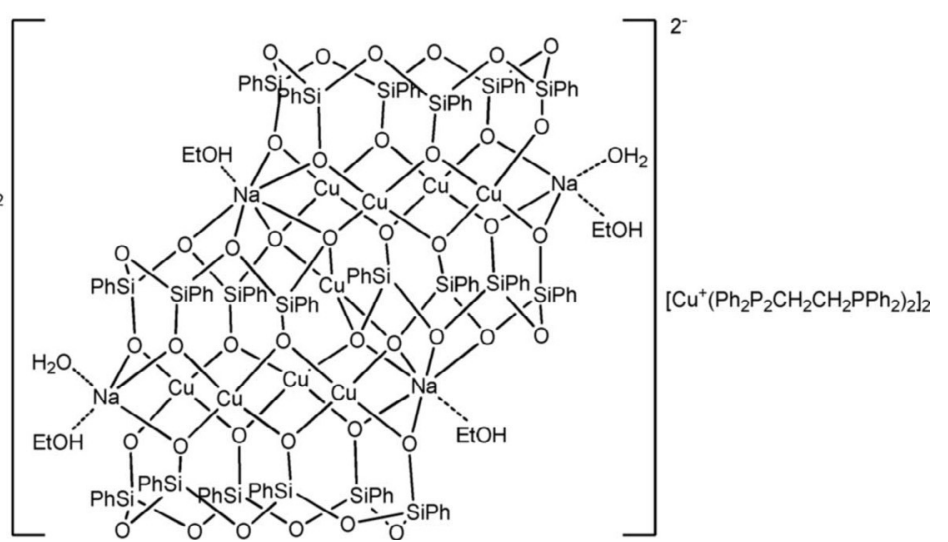

Figure 1. Structures of $\left(\mathrm{PhSiO}_{1.5}\right)_{12}(\mathrm{CuO})_{4}\left(\mathrm{NaO}_{0.5}\right)_{2}(\mathrm{Cu})_{2}(\mathrm{dppe})_{4}\left(\mathbf{1} \text {; solvating molecules of EtOH are omitted for clarity) and }\left(\mathrm{PhSiO}_{1.5}\right)_{12}(\mathrm{PhSiO})_{1.5}\right)_{8}(\mathrm{CuO})_{8}$ $\left(\mathrm{NaO}_{0.5}\right)_{4}\left\{\mathrm{Cu}\left(\mathrm{O}_{0.5}\right)_{4}\right\}(\mathrm{Cu})_{2}(\mathrm{dppe})_{4}(2$; solvating molecules of EtOH are omitted for clarity). 
pounds 1 and 2 contain a CLMS fragment as an anionic component, and $\mathrm{Cu}(\mathrm{dppe})_{2}$ fragments serve as cationic fragments to balance the charge.

This intriguing feature of CLMS formation, to the best of our knowledge, has not been described previously in the chemistry of metallasilsesquioxanes. Several unusual features of both complexes are notable. Previously, the presence of additional organic ligands in the CLMS formation medium provoked the formation of complexes in which both silsesquioxane and additional ligands (e.g., triphenylphosphine oxide, ${ }^{[15]} N, N, N^{\prime}, N^{\prime}$-tetramethyl-p-phenylenediamine ${ }^{[16]}$ trimethylphosphine, ${ }^{[17]}$ tris[2(dimethylamino)ethyl]amine, ${ }^{[18]}$ pyrazine ${ }^{[19]}$ ) coordinate metal ions of the same cage compound.

As opposed to this "ligand synergy" situation, 1 and $\mathbf{2}$ represent another "ligand antagonism" principle of complexation. Namely, the Cu ions of both $\mathbf{1}$ and $\mathbf{2}$ are redistributed between different $(\mathrm{O}$ and $\mathrm{P})$ ligands to give rise to the two-component products, in which silsesquioxane O-ligands form an anionic cage fragments and phosphine P-ligands provide cationic $\mathrm{Cu}(\mathrm{dppe})_{2}$ fragments. Notably, the compositions of the silsesquioxane cage components of $\mathbf{1}$ and $\mathbf{2}$ are different to each other. At first sight, the cage component in $\mathbf{1}$ is well known in the chemistry of CLMSs. ${ }^{[116,12-13]}$ Its sandwich-like structure is characterized by the presence of the two cyclic $\left(\mathrm{PhSiO}_{1.5}\right)_{6}$ ligands (which give a charge of -12 ) that coordinate the $\mathrm{Cu}_{4^{-}}$ containing core (which give a charge of +8 ). Notably, for all early examples of such CLMS motifs, four additional bearers of positive charge (e.g., $\mathrm{Na}^{+}, \mathrm{Li}^{+}, \mathrm{Cs}^{+}$) were observed, which is logical to balance the charge of the CLMS. According to this logic, two $\mathrm{Na}$ cations in the composition of $\mathbf{1}$ are clearly not enough to balance the negative charge (from the silsesquioxane ligands), and the appearance of two $\left[\mathrm{Cu}^{\prime}(\mathrm{dppe})_{2}\right]^{+}$fragments becomes essential to form the final complex (Figure 2).

In turn, the silsesquioxane cage component of $\mathbf{2}$ is unprecedented. First, the nonacopper(II) silsesquioxane cage of $\mathbf{2}$ joins the very small family of nonanuclear CLMSs (the first and only

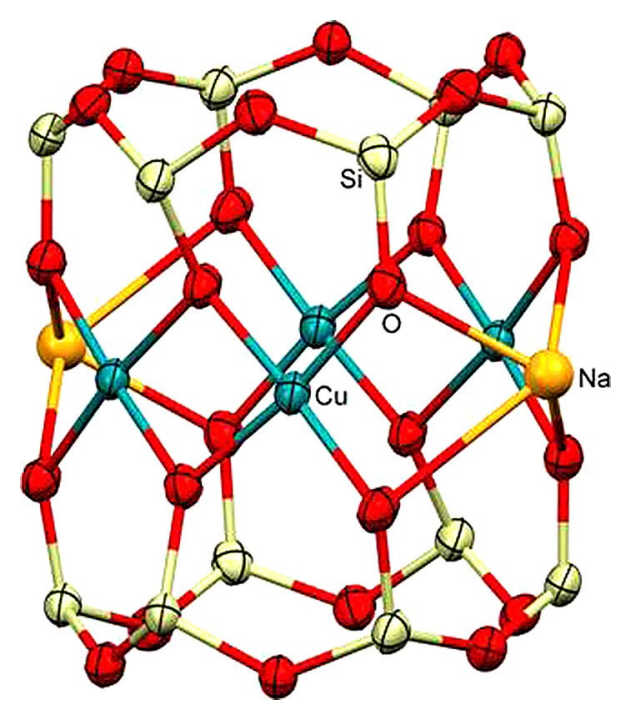

Figure 2. Copper silsequioxane cage in 1. Color code: $\mathrm{Si}=$ light yellow, $\mathrm{O}=$ red, $\mathrm{Cu}=$ blue, $\mathrm{Na}=$ yellow. known representative of that family was reported by some of us recently ${ }^{[20]}$ ). The anionic nonacopper cage of $\mathbf{2}$ possesses principal differences in its structure both from the compound described in Ref. [20] and from all other types of CLMSs. In the composition of $\mathbf{2}$, the two sandwich-like tetracopper fragments are joined by a central (ninth) Cu ion. Such a unique "fused" structure is possible because of the involvement of two types of silsesquioxane ligands: two cyclic $\left(\mathrm{PhSiO}_{1.5}\right)_{6}$ and two acyclic $\left(\mathrm{PhSiO}_{1.5}\right)_{4}$ ligands. The latter are the rarest type of silsesquioxane fragments and are able to coordinate metal ions in CLMSs. To the best of our knowledge, the only observation of such a ligand in the composition of CLMS was reported by some of us for a Mn-containing silsesquioxane. ${ }^{[21]}$ Similar to 1 , the negative charge from the silsesquioxane matrix of $\mathbf{2}$ is balanced (along with $\mathrm{Cu}^{\prime \prime}$ ions of cage component) by four $\mathrm{Na}^{+}$cations and two $\left[\mathrm{Cu}^{\prime}(\mathrm{dppe})_{2}\right]^{+}$fragments (Figure 3).

As we were interested in the further investigation of this nontrivial chemistry, we performed some additional experiments (Scheme 2). First, a change of the reactant ratio let us to isolate product $\mathbf{3}$, which is a rare instance of a compound that includes different (by their nuclearity) CLMS compositions in the same complex. This product $\mathbf{3}$ involves two types of com-

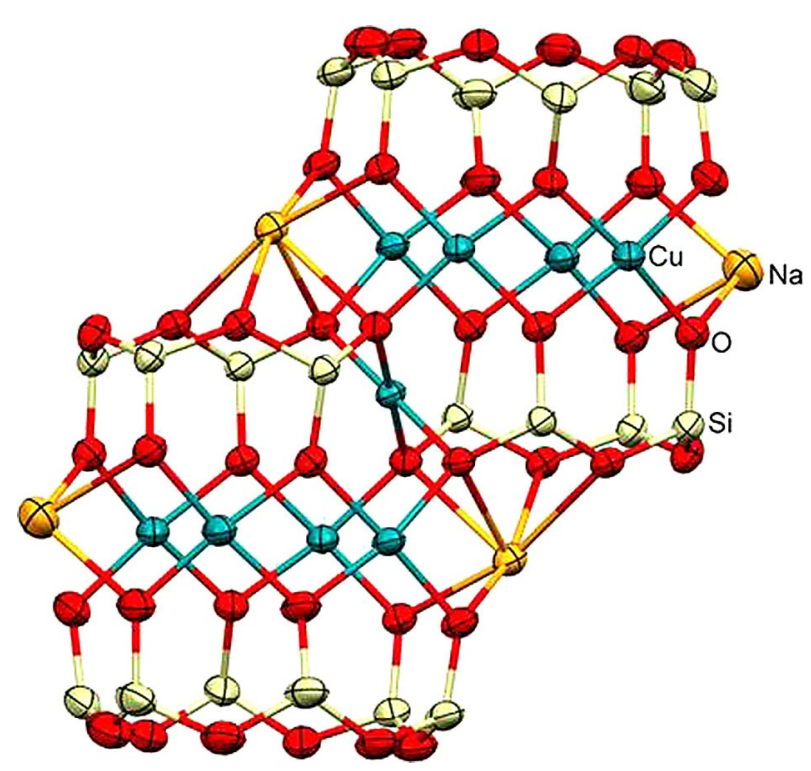

Figure 3. Copper silsequioxane cage in 2. Color code: $\mathrm{Si}=$ light yellow, $\mathrm{O}=$ red, $\mathrm{Cu}=$ blue, $\mathrm{Na}=$ yellow.

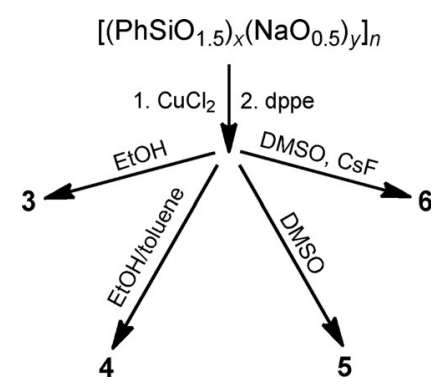

Scheme 2. Cu,Na-phenylsilsesquioxane synthesis tuning. 


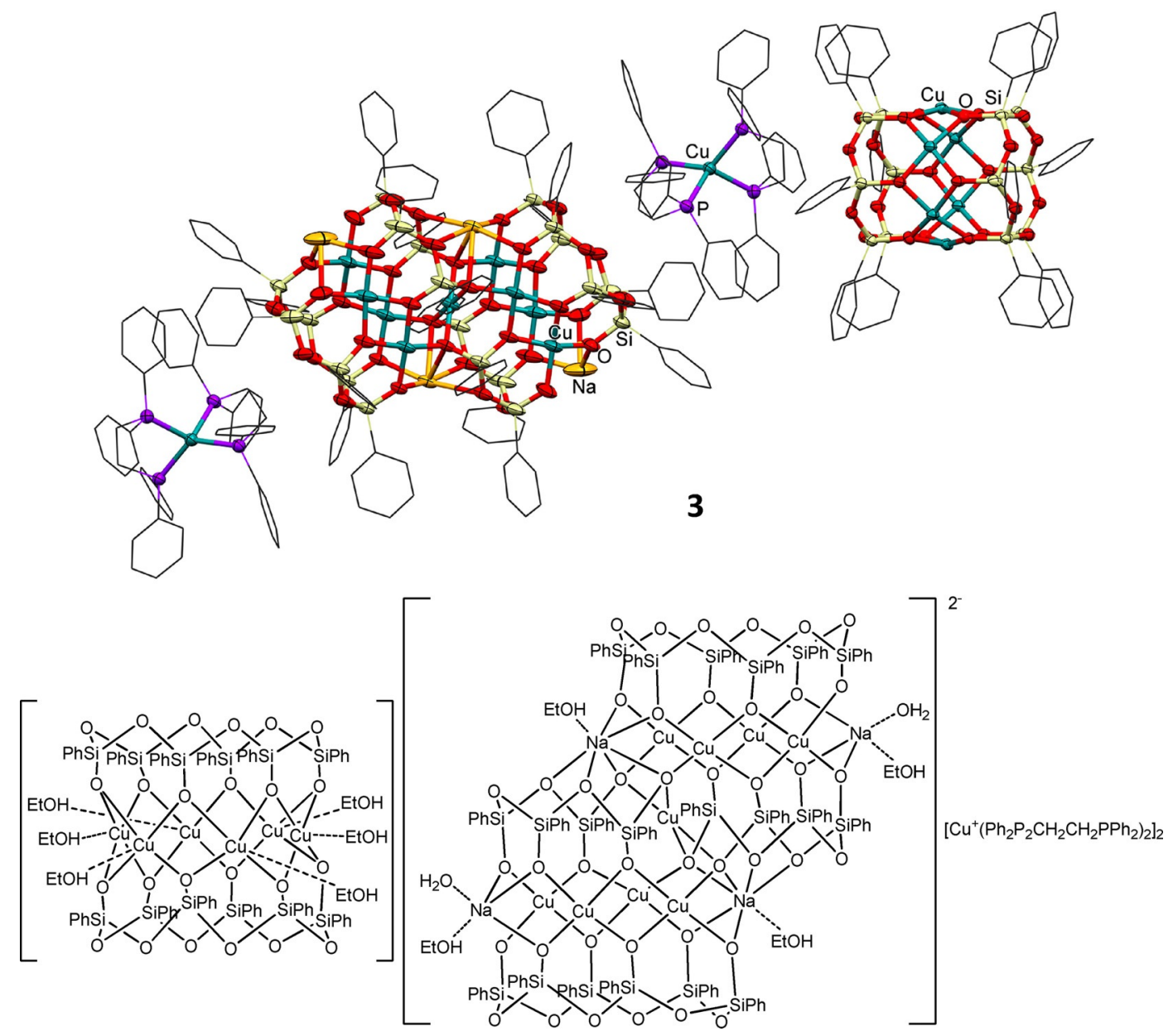

Figure 4. Structures of $\left[\left(\mathrm{PhSiO}_{1.5}\right)_{12}\left(\mathrm{PhSiO}_{1.5}\right)_{8}(\mathrm{CuO})_{8}\left(\mathrm{NaO}_{0.5}\right)_{4}\left\{\mathrm{Cu}\left(\mathrm{O}_{0.5}\right)_{4}\right\}\right]\left[\mathrm{Cu}(\mathrm{dppe})_{2}\right]_{2}\left[\left(\mathrm{PhSiO}{ }_{1.5}\right)_{12}(\mathrm{CuO})_{6}\right]$ (3; solvating molecules of water and EtOH are omitted for clarity).

ponents: (i) compound 2 and (ii) a hexacopper silsesquioxane with a cylinder-like structure (Figure 4).

Then, we tried to optimize the conditions of the synthesis of dppe-containing CLMSs. Previously, the syntheses of 1-3 were performed with heating to reflux because of the low solubility of dppe in ethanol at room temperature. The replacement of ethanol with an ethanol/toluene mixture (Scheme 2) allowed us to synthesize $\mathbf{2}$ at a lower temperature and to isolate product 4 (Figure 5) as an ethanol/toluene complex in a higher yield than 2 ( 46 vs. $17 \%$ ).

Then, we explored the suitability of other reaction systems to prepare structural analogues of $\mathbf{2}$. To our surprise, the replacement of ethanol by DMSO (Scheme 2) led to some reorganization of the structure. Isolated as a DMSO complex, $\mathbf{5}$ is similar (with regard to the silsesquioxane skeleton) to 2 . However, the phosphine components present in $\mathbf{2}$ do not participate in the formation of $\mathbf{5}$. As a result, $\mathbf{5}$ may be described as a one-component analogue of $\mathbf{2}$, in which electroneutrality is reached by the involvement of two additional $\mathrm{Na}^{+}$centers (Figure 6).

The elimination of a phosphine component if DMSO is used as the reaction medium was reproducible. Synthesis under conditions close to those used for the formation of $\mathbf{5}$ with the partial replacement of $\mathrm{Na}$ ions by $\mathrm{Cs}$ ions (Scheme 2) resulted in the isolation of the trimetallic $\mathrm{Cu}_{9} \mathrm{Na}_{3} \mathrm{Cs}_{3}$ product 6 , which also contained no dppe (Figure 7). To our delight, 6 differs from 5 by its ability to pack into a 2D coordination polymer net. We suggest that this could be because of the different location of the Cs ions in the structure of $\mathbf{6}$ (at "crown ether" positions, coordinated by six-membered siloxane rings) to the $\mathrm{Na}$ ions in $\mathbf{5}$. As a result, the coordination polymer $\mathbf{6}$, in comparison to $\mathbf{1 - 5}$, is much less soluble (1-5 are easily soluble in many polar organic solvents, except for short-chain alcohols).

\section{Solid-state structures and topological analysis}

Notably, as for globular and prismatic Cu CLMSs, ${ }^{[116,12-13]}$ a bulky phenyl coating prevents the condensation of neighboring cages. Bonding between the alkaline atoms of the CLMS cage and the $\mathrm{O}$ atoms of silsesquioxanes of neighboring molecules is not observed in 1-6. At the same time, as some of us observed previously, the replacement of $\mathrm{Na}$ with $\mathrm{Cs}$ favors the formation of coordination polymers, ${ }^{[13]}$ here through bridging solvent molecules. In 6, 2D polymers can be found with CLMSs connected through bridging DMSO molecules and fully occupied positions of $\mathrm{Cs}$. The chains are also somewhat connected 


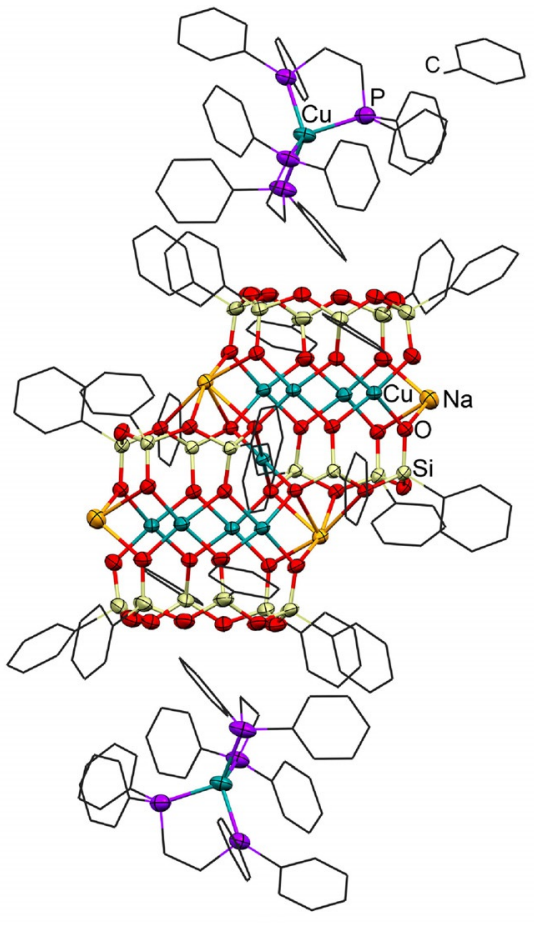

4

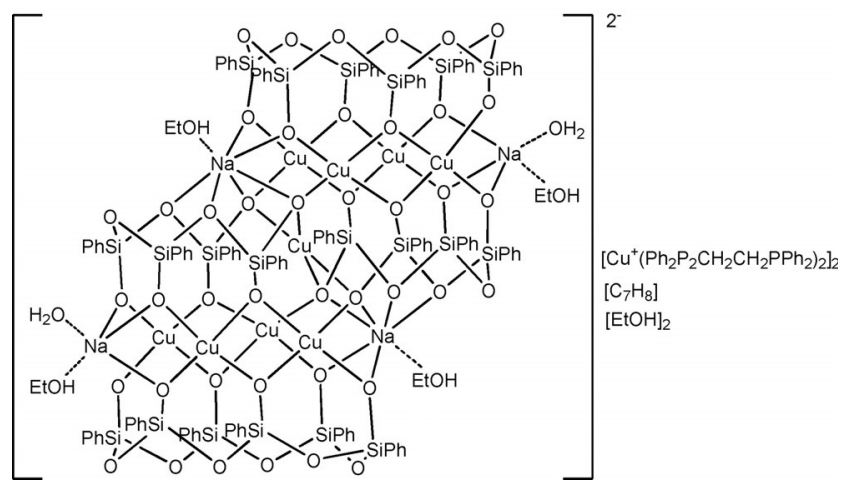

Figure 5. Structures of $\left[\left(\mathrm{PhSiO}_{1.5}\right)_{12}\left(\mathrm{PhSiO}_{1.5}\right)_{8}(\mathrm{CuO})_{8}\left(\mathrm{NaO}_{0.5}\right)_{4}\left\{\mathrm{Cu}\left(\mathrm{O}_{0.5}\right)_{4}\right\}\right]$ $\left[\mathrm{Cu}(\mathrm{dppe})_{2}\right]_{2}$ (4; solvating molecules of water and $\mathrm{EtOH}$ are omitted for clarity). through partially occupied positions of $\mathrm{Cs}$ atoms to a quasi-sql net (in which CLMSs form a net with a square-planar topology).

In terms of the $\mathrm{Cu}$ nuclearity, all products reported here could be divided into three categories: tetra- (1), hexa- (3), and nonanuclear complexes (2-6). A description of the topology of the first two types was given by some of us recently. ${ }^{[22]}$ In turn, nonanuclear $\mathrm{Cu}$ clusters in terms of $N D k-m$ notation ${ }^{[23]}$ are 1,2,4 M9-1 clusters in which 1,2,4 are the coordination numbers of topologically nonequivalent nodes, $M$ denotes a discrete cluster, 9 is the number of metal atoms in the cluster, and 1 is a classification number to distinguish topologically distinct clusters with equal NDk parameters (Figure 8). In these clusters $\mathrm{Cu}$ atoms realize three different types of connectivity with different orientations of the equatorial and axial planes for connected atoms. Notably, these types of clusters were not only absent in CLMSs synthesized previously but were not observed previously in other metal clusters (see the TTD collection at http://topospro.com/databases/ttd/).

\section{Catalytic oxidation}

\section{Oxidation of alkanes and alcohols with peroxides}

Polynuclear Cu derivatives constitute active reaction centers of certain oxidizing enzymes (e.g., oxidases, particulate methane monooxygenase (pMMO), $\alpha$-hydroxylating monooxygenase). ${ }^{[24]}$ Various Cu complexes are enzyme models, ${ }^{[25]}$ and some Cu-catalyzed oxidations of cyclohexane have been reported. ${ }^{[25]}$ Recently, we found that copper silsesquioxanes catalyze the efficient oxidation of benzene, alkanes, and alcohols with peroxides. $^{[20,22,26]}$

Here, we report on the interaction of $\mathbf{1}$ and $\mathbf{4}$ with peroxides in the presence of alkanes, $\mathrm{RH}$, which afforded oxygenated products, namely, alkyl hydroperoxides, ROOH. Secondary alcohols have been oxidized catalytically into ketones.

Kinetic plots of the product accumulation in cyclohexane oxidation are presented in Figure 9. The dependence of the initial oxidation rate $W_{0}$ on the initial concentration of catalyst 4 and cyclohexane are shown in Figure 10. The heating of a solution
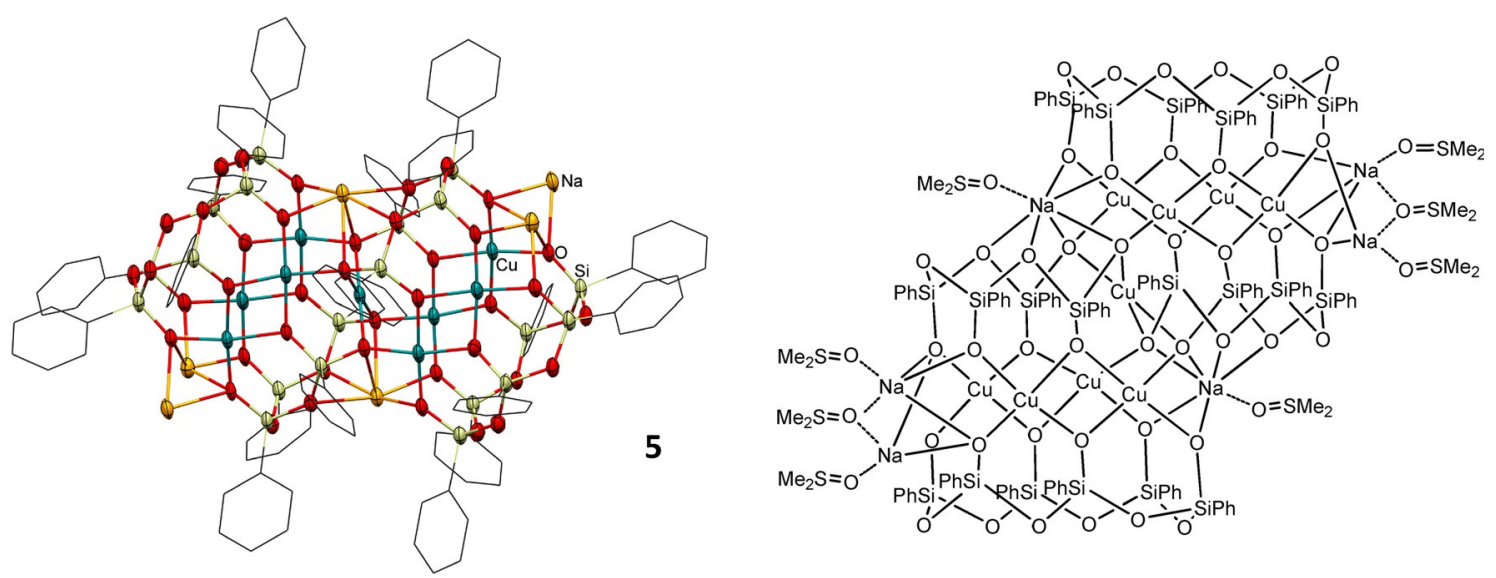

Figure 6. Structures of $\left[\left(\mathrm{PhSiO}_{1.5}\right)_{12}\left(\mathrm{PhSiO}_{1.5}\right)_{8}(\mathrm{CuO})_{8}\left(\mathrm{NaO}_{0.5}\right)_{4}\left\{\mathrm{Cu}\left(\mathrm{O}_{0.5}\right)_{4}\right\} \mathrm{Na}_{2}\right]$ (5; solvating molecules of DMSO are omitted for clarity). 

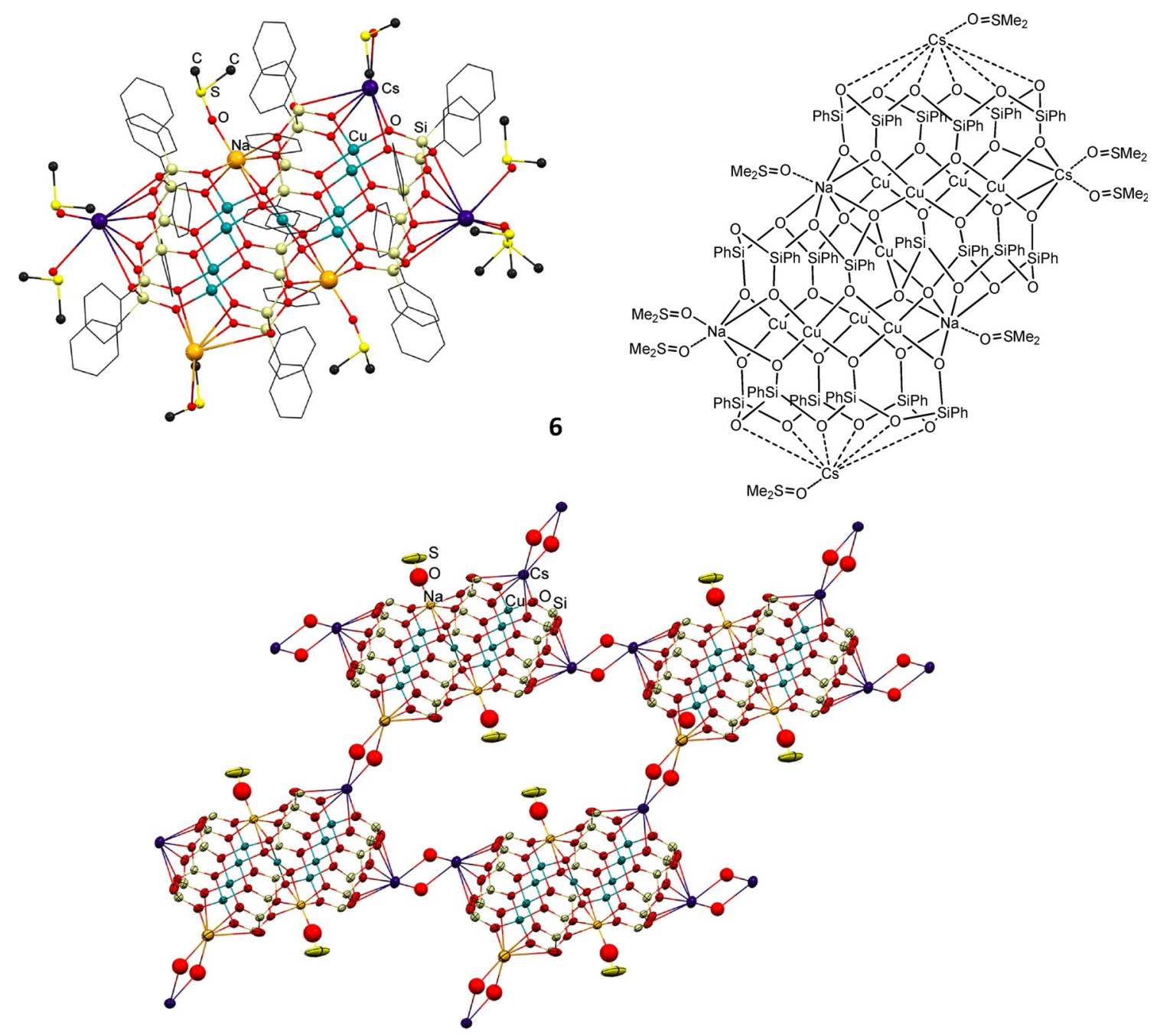

Figure 7. Top left: molecular structure of $\left[\left(\mathrm{PhSiO}_{1.5}\right)_{12}\left(\mathrm{PhSiO}_{1.5}\right)_{8}(\mathrm{CuO})_{8}\left(\mathrm{NaO}_{0.5}\right)_{3}\left(\mathrm{CsO}_{0.5}\right)\left\{\mathrm{Cu}\left(\mathrm{O}_{0.5}\right)_{4}\right\} \mathrm{Cs}_{2}\right](6$; solvating molecules of DMSO are omitted for clarity). Top right: ChemDraw structure of 6 . Bottom: 2D coordination polymer structure of 6 .
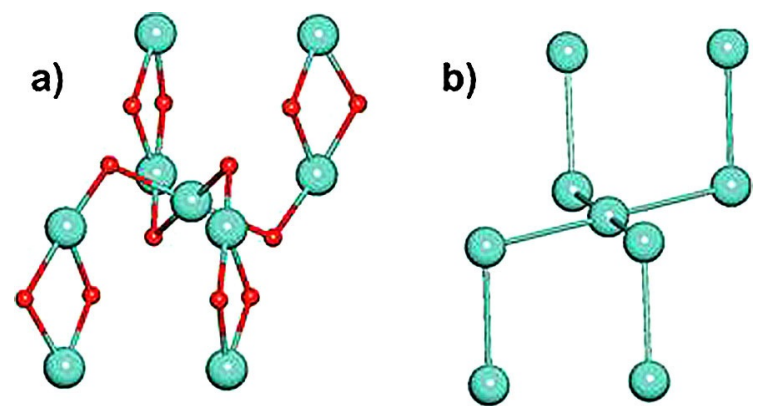

Figure 8. a) Nonacopper-containing clusters connected by bridging atoms in CLMSs 2-6 and b) scheme of cluster connectivity.

of cyclohexanol and tert-butyl hydroperoxide (TBHP) in acetonitrile gave cyclohexanone in $72 \%$ yield after $5 \mathrm{~h}$ (Figure 11). The oxidation of 1-phenylethanol afforded acetophenone in $76 \%$ yield after $10 \mathrm{~h}$ (Figure 12 ).

We also tested 1 in the catalytic oxidation of cyclohexane and alcohols. The heating of a solution of cyclohexane $(0.46 \mathrm{M})$ and $\mathrm{H}_{2} \mathrm{O}_{2}(2 \mathrm{M})$ in acetonitrile in the presence of $1\left(5 \times 10^{-4} \mathrm{M}\right)$ at $60^{\circ} \mathrm{C}$ for $1 \mathrm{~h}$ gave cyclohexanol $(0.039 \mathrm{M})$ and cyclohexanone $(0.015 \mathrm{M})$ with a total turnover number (TON) of 108 . Notably, in this case the addition of $\mathrm{HNO}_{3}(0.05 \mathrm{M})$ led to a sharp decrease of the product yield $(0.004$ and $0.00027 \mathrm{M}$ of cyclohexanol and cyclohexanone, respectively). The reaction of cyclohexanol $(0.38 \mathrm{M})$ with TBHP $(1.2 \mathrm{M})$ catalyzed by $1\left(5 \times 10^{-4} \mathrm{M}\right)$ at $60^{\circ} \mathrm{C}$ after $3 \mathrm{~h}$ gave cyclohexanone (70\%). Acetophenone in $94 \%$ yield was obtained under the same conditions from 1phenylethanol $(0.49 \mathrm{M})$.

\section{Catalytic oxidation of alcohols and amines to produce amides}

Previously, we reported the ability of CLMSs to catalyze the oxidative formation of amides from alcohols. ${ }^{[6,22,28]}$ This reaction could be performed using $\mathrm{Cu}_{1}{ }^{[29]} \mathrm{Fe}_{1}^{[30]}$ or $\mathrm{Zn}_{1}^{[31]}$ but the catalyst loading could not be decreased below $1 \mathrm{~mol} \%$. With the use of CLMSs, this reaction was efficient with dramatically lower loadings (down to $100 \mathrm{ppm}$ of $\mathrm{Cu}^{[22]}$ and $500 \mathrm{ppm}$ of $\mathrm{Fe}^{[6 c, 28]}$ ). As 1 and 4 present really atypical structures, their catalytic activity was also evaluated in the transformation of benzylic alcohol into benzamide. Reactions were performed using as low as 

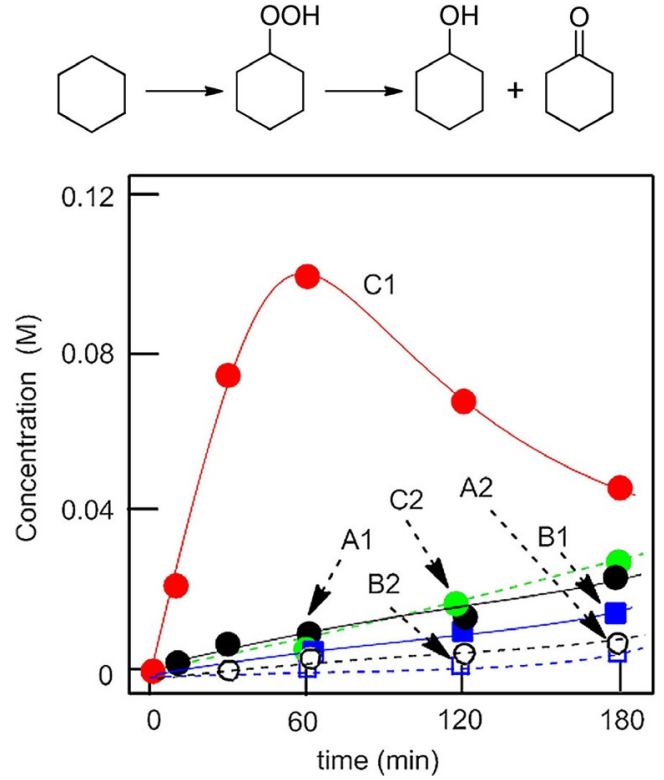

Figure 9. Top: general scheme for the oxidation of cyclohexane. Bottom: ac cumulation of cyclohexanol (curve 1) and cyclohexanone (curve 2) in the course of cyclohexane oxidation with $\mathrm{H}_{2} \mathrm{O}_{2}$ in acetonitrile in air. Conditions: 4, $5 \times 10^{-4} \mathrm{M}$; cyclohexane, $0.46 \mathrm{M} ; \mathrm{H}_{2} \mathrm{O}_{2}(50 \%$ aqueous, $2 \mathrm{M})$. A) $20^{\circ} \mathrm{C}$; in the presence of $\mathrm{HNO}_{3}, 0.05 \mathrm{M}$; maximum yield of oxygenates is $20 \%$ after $1 \mathrm{~h}$; $\mathrm{TON}=182$. B) $60^{\circ} \mathrm{C}$; in the presence of $\mathrm{HNO}_{3}, 0.1 \mathrm{M}$. C) $60^{\circ} \mathrm{C}$; in the absence of $\mathrm{HNO}_{3}$. In all cases concentrations of the oxygenates were measured after the addition of $\mathrm{PPh}_{3}$ to the reaction sample. ${ }^{[27]}$

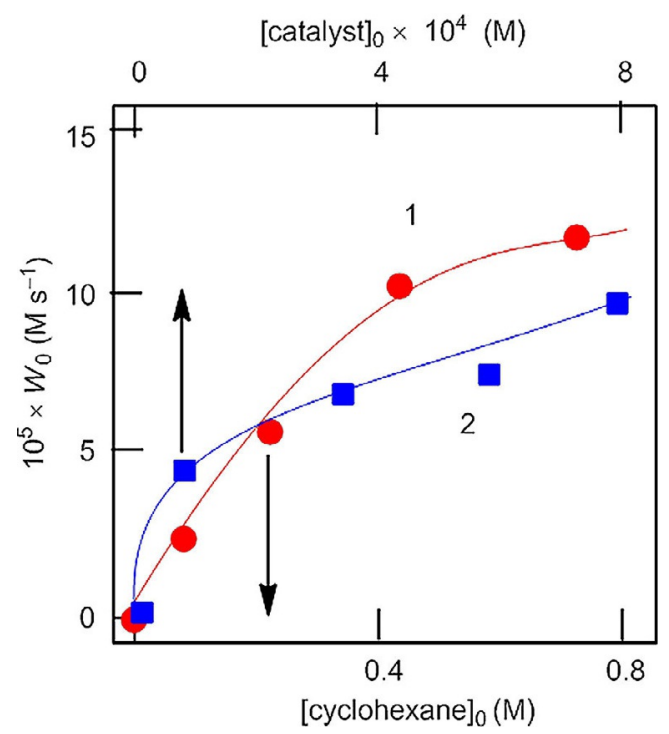

Figure 10. Oxidation of cyclohexane with $\mathrm{H}_{2} \mathrm{O}_{2}$ in acetonitrile in air. Conditions: Catalyst $4,5 \times 10^{-4} \mathrm{M} ; \mathrm{H}_{2} \mathrm{O}_{2}(50 \%$ aqueous, $2 \mathrm{M})$ at $60^{\circ} \mathrm{C}$ in the presence of $\mathrm{HNO}_{3}, 0.05 \mathrm{M}$. Concentrations of the oxygenates were measured after the addition of $\mathrm{PPh}_{3}$ to the reaction sample.

$100 \mathrm{ppm}$ of $\mathrm{Cu}$ and calcium carbonate $99.995 \%$ pure to ensure that $\mathrm{Cu}$ was the only metal responsible for the catalysis. Thus, benzylic alcohol was used in the presence of various primary and secondary amines with TBHP as an oxidant in acetonitrile heated to reflux for $24 \mathrm{~h}$ (Table 1). Notably, the concomitant use of the ammonium salt and calcium carbonate was compul-

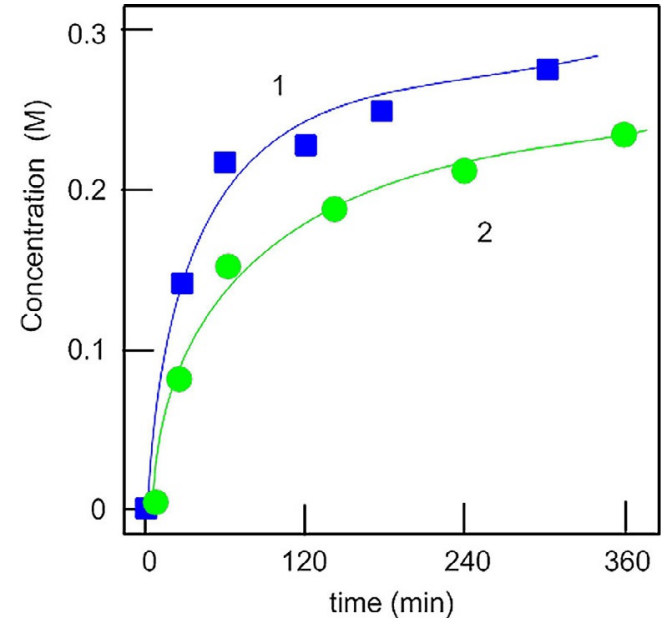

Figure 11. Accumulation of cyclohexanone (curve 1) in the course of cyclohexanol $(0.38 \mathrm{M})$ oxidation with TBHP $(70 \%$ aqueous, $1.2 \mathrm{M})$ catalyzed by 4 $\left(5 \times 10^{-4} \mathrm{M}\right)$ in acetonitrile in air at $60^{\circ} \mathrm{C}$. Maximum yield of oxygenates is $72 \%$ after $5 \mathrm{~h} ; \mathrm{TON}=550$. Curve 2 : the same reaction in the presence of $\mathrm{HNO}_{3}, 0.05 \mathrm{M}$. Concentrations of the ketone were measured after the addition of $\mathrm{PPh}_{3}$ to the reaction sample.
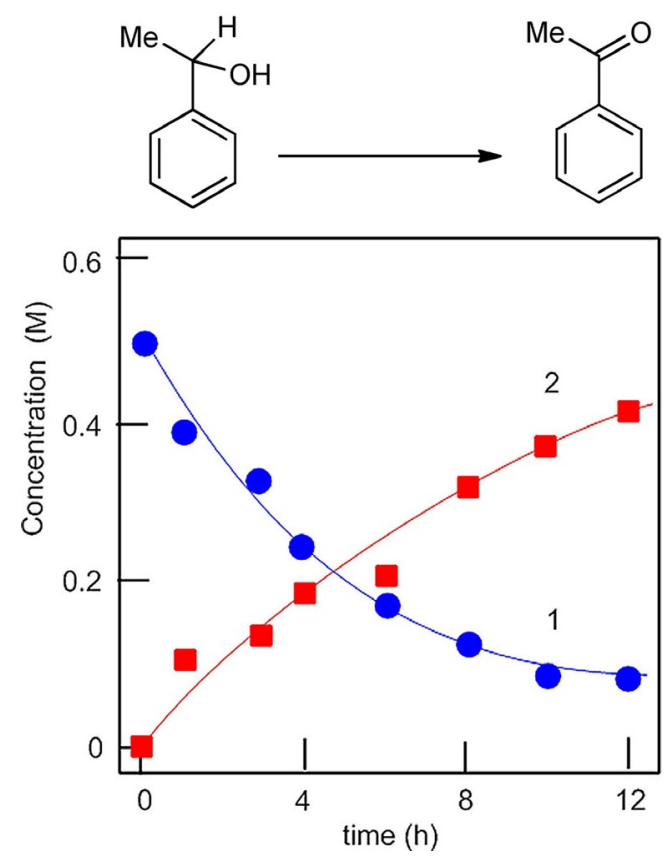

Figure 12. Top: general scheme for the oxidation of 1-phenylethanol. Bottom: accumulation of acetophenone (curve 2) and 1-phenylethanol consumption (curve 1 ) in the course of 1-phenylethanol $(0.5 \mathrm{M})$ oxidation with TBHP $(70 \%$ aqueous, $1.2 \mathrm{M})$ catalyzed by $4\left(5 \times 10^{-4} \mathrm{M}\right)$ in acetonitrile in air at $60{ }^{\circ} \mathrm{C}$ in the presence of $\mathrm{HNO}_{3}, 0.05 \mathrm{M}$.

sory to release free amine slowly in the reaction mixture to observe good conversions. Gratifyingly, even though a really low amount of $\mathrm{Cu}$ was used, the desired amides could be isolated in good yields (64-84\%). Primary amines (Table 1, entries 1-6) were converted slightly more easily than secondary ones (Table 1, entries 7-12). CLMSs 1 and 4 behaved similarly under the reaction conditions and excellent TONs and turnover frequencies (TOFs) up to 8400 and $350 \mathrm{~h}^{-1}$, respectively, could be 


\begin{tabular}{|lllll|}
\hline Table 1. Oxidative amidation at low catalyst loading. \\
1.a]
\end{tabular}

[a] Reaction conditions: amine $\cdot \mathrm{HCl}(0.5 \mathrm{mmol})$, benzyl alcohol $(1.0 \mathrm{mmol})$, $\mathrm{CaCO}_{3}(99.995 \%$ pure; $0.5 \mathrm{mmol})$, TBHP $(5.5 \mathrm{~m}$ in nonane, $2.5 \mathrm{mmol}), 1$ or $4(100 \mathrm{ppm}$ of $\mathrm{Cu}), \mathrm{CH}_{3} \mathrm{CN}(1 \mathrm{~mL}), 80^{\circ} \mathrm{C}, 24 \mathrm{~h}$. Isolated yields are given. [b] TON $=(\mathrm{mmol}$ of product $) /(\mathrm{mmol}$ of $\mathrm{Cu})$. [c] TOF $=\mathrm{TON} /($ reaction time).

obtained. In comparison, if $2 \mathrm{~mol} \%$ of CuO was used in the original study on Cu-catalyzed oxidative amidation, ${ }^{[29 a]}$ the TON and TOF values did not exceed 44 and $11 \mathrm{~h}^{-1}$, respectively. Hence, low-loading CLMS catalysis was extremely efficient.

\section{Conclusion}

We present a detailed study of a simple new method to prepare cage-like metallasilsesquioxanes. This method implies the use of a bidentate phosphine (1,2-bis(diphenylphosphino)ethane; dppe) ligand as a key reagent in the formation of $\mathrm{Cu}$ and $\mathrm{Na}$-based cage products with different nuclearities $\left(\mathrm{Cu}_{4} \mathrm{Na}_{2}\right.$ and $\mathrm{Cu}_{9} \mathrm{Na}_{4}$ ). The involvement of two types of ligands (silsesquioxane and phosphine) is responsible for an unprecedented redistribution of $\mathrm{Cu}$ ions between two types of ionic components (cage $\mathrm{Cu}, \mathrm{Na}$-silsesquioxane and $\mathrm{Cu}(\mathrm{dppe})_{2}$ ) to form the complex product. This reaction was sensitive to the solvent system, which allowed us to isolate additional examples of fascinating cage silsesquioxane architectures $\left(\mathrm{Cu}_{9} \mathrm{Na}_{6}\right.$ and $\left.\mathrm{Cu}_{9} \mathrm{Na}_{3} \mathrm{Cs}_{3}\right)$. The first example of the evaluation of complexes of this family as precatalysts in homogeneous catalysis revealed the high activity of these complexes in oxidations with $\mathrm{H}_{2} \mathrm{O}_{2}$ and tert-butyl hydroperoxide. In turn, the catalytic formation of benzamides was promising as a $\mathrm{Cu}$ loading as low as $100 \mathrm{ppm}$ with the use of $\mathbf{1}$ and $\mathbf{4}$ allowed us to reach a turnover number up to 8400 and a turnover frequency up to $350 \mathrm{~h}^{-1}$.
A further focus on the synthesis of these cage-like metallasilsesquioxanes will no doubt lead to the discovery of currently unknown structural types of these cage compounds as well as the new possibilities for their catalytic applications.

\section{Experimental Section}

\section{Chemicals}

$\mathrm{PhSi}(\mathrm{OEt})_{3}(98 \%)$ and dppe (99\%) were purchased from Sigma-Aldrich. Solvents were purchased from Acros.

\section{Synthesis}

Compound 1: $\mathrm{PhSi}(\mathrm{OEt})_{3}(1 \mathrm{~g}, 4.16 \mathrm{mmol})$ and $\mathrm{NaOH}(0.194 \mathrm{~g}$, $4.85 \mathrm{mmol})$ were heated to reflux in ethanol $(60 \mathrm{~mL})$ for $1.5 \mathrm{~h}$. $\mathrm{CuCl}_{2}(0.28 \mathrm{~g}, 2.08 \mathrm{mmol})$ was added, and the resulting blue mixture was stirred without heating for $1 \mathrm{~h}$. Afterwards, dppe $(0.414 \mathrm{~g}$, $1.04 \mathrm{mmol}$ ) was added at once, and the resulting mixture was heated under reflux for $3 \mathrm{~h}$. The hot solution was filtered to remove the precipitate. The crystallization of the filtrate over 1 week gave a crystalline material, and several single crystals of which were used for XRD analysis (1.4EtOH, see the Supporting Information for details). Yield $0.40 \mathrm{~g}(42 \%)$. Elemental analysis calcd (\%) for $\left[\left(\mathrm{PhSiO}_{1.5}\right)_{12}(\mathrm{CuO})_{4}\left(\mathrm{NaO}_{0.5}\right)_{2}\right]\left[\mathrm{Cu}(\mathrm{dppe})_{4}\right]_{2}(3651.23)$ : $\mathrm{Si} 9.23, \mathrm{Cu}$ 10.44, Na 1.26, P 6.79; found (for vacuum-dried sample): Si 9.17, Cu 10.38, Na 1.20, P 6.72 .

Compound 2: $\mathrm{PhSi}(\mathrm{OEt})_{3}(1 \mathrm{~g}, 4.16 \mathrm{mmol})$ and $\mathrm{NaOH}(0.216 \mathrm{~g}$, $5.40 \mathrm{mmol}$ ) were heated to reflux in ethanol $(60 \mathrm{~mL})$ for $1.5 \mathrm{~h}$. $\mathrm{CuCl}_{2}(0.28 \mathrm{~g}, 2.08 \mathrm{mmol})$ was added, and the resulting blue mixture was stirred without heating for $1 \mathrm{~h}$. Afterwards, dppe $(0.414 \mathrm{~g}$, $1.04 \mathrm{mmol}$ ) was added at once, and the resulting mixture was heated to reflux for $3 \mathrm{~h}$. The hot solution was filtered to remove the precipitate. The crystallization of filtrate over 1 week gave a crystalline material, and several single crystals were used for XRD analysis $\left(2 \cdot 8 \mathrm{EtOH} \cdot 2 \mathrm{H}_{2} \mathrm{O}\right.$, see the Supporting Information for de-

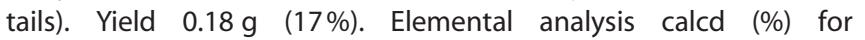
$\left[\left(\mathrm{PhSiO}_{1.5}\right)_{12}\left(\mathrm{PhSiO}_{1.5}\right)_{8}(\mathrm{CuO})_{8}\left(\mathrm{NaO}_{0.5}\right)_{4}\left\{\mathrm{Cu}\left(\mathrm{O}_{0.5}\right)_{4}\right\}\right]\left[\mathrm{Cu}(\mathrm{dppe})_{2}\right]_{2}$ (5160.39): Si 10.89, Cu 13.55, Na 1.78, P 4.80; found (for vacuumdried sample): Si 10.81, Cu 13.46, Na 1.60, P 4.71.

Compound 3: $\mathrm{PhSi}(\mathrm{OEt})_{3}(1 \mathrm{~g}, 4.16 \mathrm{mmol})$ and $\mathrm{NaOH}(0.188 \mathrm{~g}$, $4.70 \mathrm{mmol})$ were heated to reflux in ethanol $(60 \mathrm{~mL})$ for $1.5 \mathrm{~h}$. $\mathrm{CuCl}_{2}(0.28 \mathrm{~g}, 2.08 \mathrm{mmol})$ was added, and the resulting blue mixture was stirred without heating for $1 \mathrm{~h}$. Afterwards, dppe $(0.414 \mathrm{~g}$, $1.04 \mathrm{mmol}$ ) was added at once, and the resulting mixture was heated to reflux for $3 \mathrm{~h}$. The hot solution was filtered to remove the precipitate. The crystallization of the filtrate over 1 week gave a crystalline material, several single crystals of which were used for XRD analysis $\left(3 \cdot 12 \mathrm{EtOH} \cdot 2 \mathrm{H}_{2} \mathrm{O}\right)$, see the Supporting Information for details). Yield $0.12 \mathrm{~g}$ (13\%). Elemental analysis calcd (\%) for $\left[\left(\mathrm{PhSiO}_{1.5}\right)_{12}\left(\mathrm{PhSiO}_{1.5}\right)_{8}(\mathrm{CuO})_{8}\left(\mathrm{NaO}_{0.5}\right)_{4}\left\{\mathrm{Cu}\left(\mathrm{O}_{0.5}\right)_{4}\right\}\right]\left[\mathrm{Cu}(\mathrm{dppe})_{2}\right]_{2}[(\mathrm{PhSi}-$ $\left.\mathrm{O}_{1.5}\right)_{12}(\mathrm{CuO})_{6}$ ] (7187.93): Si 12.50, Cu 15.03, Na 1.28, P 3.45; found (for vacuum-dried sample): Si 12.41, Cu 14.92, Na 1.22, P 3.39.

Compound 4: $\mathrm{PhSi}(\mathrm{OEt})_{3}(1 \mathrm{~g}, 4.16 \mathrm{mmol})$ and $\mathrm{NaOH}(0.216 \mathrm{~g}$, $5.40 \mathrm{mmol}$ ) were heated to reflux in ethanol $(60 \mathrm{~mL})$ for $1.5 \mathrm{~h}$. $\mathrm{CuCl}_{2}(0.28 \mathrm{~g}, 2.08 \mathrm{mmol})$ was added, and the resulting blue mixture was stirred without heating for $1 \mathrm{~h}$. Afterwards, dppe $(0.414 \mathrm{~g}$, $1.04 \mathrm{mmol}$ ) dissolved in toluene $(45 \mathrm{~mL})$ was added at once, and the resulting mixture was stirred for $2 \mathrm{~h}$. The solution was filtered to remove the precipitate. The crystallization of the filtrate over 2 weeks gave a crystalline material, and several single crystals were 
used for XRD analysis $\left(4 \cdot 6 \mathrm{EtOH} \cdot 2 \mathrm{H}_{2} \mathrm{O} \cdot 2 \mathrm{C}_{7} \mathrm{H}_{8}\right.$, see the Supporting Information for details). Yield $0.49 \mathrm{~g}(46 \%)$. Elemental analysis calcd (\%) for $\left[\left(\mathrm{PhSiO}_{1.5}\right)_{12}\left(\mathrm{PhSiO}_{1.5}\right)_{8}(\mathrm{CuO})_{8}\left(\mathrm{NaO}_{0.5}\right)_{4}\left\{\mathrm{Cu}\left(\mathrm{O}_{0.5}\right)_{4}\right\}\right]\left[\mathrm{Cu}(\mathrm{dppe})_{2}\right]_{2}$ (5160.39): Si 10.89, Cu 13.55, Na 1.78, P 4.80; found (for vacuumdried sample): Si 10.81, Cu 13.46, Na 1.60, P 4.71.

Compound 5: $\mathrm{PhSi}(\mathrm{OEt})_{3}(1 \mathrm{~g}, 4.16 \mathrm{mmol})$ and $\mathrm{NaOH}(0.216 \mathrm{~g}$, $5.40 \mathrm{mmol}$ ) were heated to reflux in ethanol $(50 \mathrm{~mL})$ for $1.5 \mathrm{~h}$. $\mathrm{CuCl}_{2}(0.28 \mathrm{~g}, 2.08 \mathrm{mmol})$ was added, and the resulting blue mixture was stirred without heating for $1 \mathrm{~h}$. Afterwards, dppe $(0.414 \mathrm{~g}$, $1.04 \mathrm{mmol})$ and DMSO $(60 \mathrm{~mL})$ were added at once. The resulting mixture was heated to reflux along with the simultaneous distillation of the solution to remove ethanol completely from the reaction mixture. When approximately $45 \mathrm{~mL}$ of distillate was collected, the mixture was cooled to RT and filtered to remove the precipitate. The crystallization of the filtrate over 2 weeks gave a crystalline material, and several single crystals were used for XRD analysis (5.8DMSO, see the Supporting Information for details). Yield $0.14 \mathrm{~g}$ (19\%). Elemental analysis calcd (\%) for $\left[\left(\mathrm{PhSiO}_{1.5}\right)_{12}(\mathrm{PhSi}-\right.$ $\left.\left.\mathrm{O}_{1.5}\right)_{8}(\mathrm{CuO})_{8}\left(\mathrm{NaO}_{0.5}\right)_{4}\left\{\mathrm{Cu}\left(\mathrm{O}_{0.5}\right)_{4}\right\} \mathrm{Na}_{2}\right]$ (3485.62): Si 16.12, $\mathrm{Cu}$ 16.41, $\mathrm{Na}$ 3.96, P 0.0; found (for vacuum-dried sample): Si 16.06, Cu 16.32, Na $3.870, \mathrm{P} 0.0$.

Compound 6: $\mathrm{PhSi}(\mathrm{OEt})_{3}(1 \mathrm{~g}, 4.16 \mathrm{mmol})$ and $\mathrm{NaOH}(0.216 \mathrm{~g}$, $5.40 \mathrm{mmol}$ ) were heated to reflux in ethanol $(50 \mathrm{~mL})$ for $1.5 \mathrm{~h}$. $\mathrm{CuCl}_{2}(0.28 \mathrm{~g}, 2.08 \mathrm{mmol})$ was added, and the resulting blue mixture was stirred without heating for $1 \mathrm{~h}$. Afterwards, dppe $(0.414 \mathrm{~g}$, $1.04 \mathrm{mmol})$ and DMSO $(60 \mathrm{~mL})$ were added at once. The resulting mixture was heated to reflux along with the simultaneous distillation of the solution to remove ethanol completely from the reaction mixture. When $\approx 45 \mathrm{~mL}$ of distillate was collected, CsF $(0.43 \mathrm{~g}$, $2.83 \mathrm{mmol}$ ) was added at once to the mixture. The resulting solution was heated to reflux for an additional $3 \mathrm{~h}$ then cooled to RT and filtered from the precipitate. The crystallization of the filtrate over 2 weeks gave a crystalline material, and several single crystals were used for XRD analysis (6.9DMSO, see the Supporting Information for details). Yield $0.12 \mathrm{~g}(15 \%)$. Elemental analysis calcd (\%) for $\left[\left(\mathrm{PhSiO}_{1.5}\right)_{12}\left(\mathrm{PhSiO}_{1.5}\right)_{8}(\mathrm{CuO})_{8}\left(\mathrm{NaO}_{0.5}\right)_{3}\left(\mathrm{CsO}_{0.5}\right)\left\{\mathrm{Cu}\left(\mathrm{O}_{0.5}\right)_{4}\right\} \mathrm{Cs}_{2}\right] \quad$ (3815.36): Si 14.72, Cu 14.99, Na 1.81, Cs 10.45, P 0.0; found (for vacuumdried sample): Si 14.65, Cu 14.90, Na 1.71, Cs 10.37, P 0.0.

IR spectroscopy of the bulky samples of crystalline materials of 1-6 were performed by using a Shimadzu IRPrestige-21 FTIR spectrometer $(\mathrm{KBr})$ in the $600-4000 \mathrm{~cm}^{-1}$ range. IR spectra are given in the Supporting Information.

\section{Oxidation of alcohols and alkanes}

The reactions of alcohols were performed in air by using thermostated cylindrical Pyrex vessels with vigorous stirring and MeCN as the solvent. The substrate was then added, and the reaction started on introduction of the oxidant in one portion. The concentrations of products obtained in the oxidation of 1-phylethanol after certain time intervals were measured by using ${ }^{1} \mathrm{H}$ NMR spectroscopy (solutions in $\left[D_{6}\right]$ acetone; Bruker $A M X-400$ instrument, $400 \mathrm{MHz}$ ). In the oxidation of cyclohexanol, concentrations of the substrate and products were measured by chromatography as described below for the oxidation of cyclohexane.

Oxidations of alkanes were performed analogously. Catalysts 1 or $\mathbf{4}$ and the cocatalyst $\left(\mathrm{HNO}_{3}\right)$ were introduced into the reaction mixture in the form of stock solutions in acetonitrile. The alkane was then added, and the reaction started on introduction of $\mathrm{H}_{2} \mathrm{O}_{2}$ in one portion. (CAUTION: The combination of air or $\mathrm{O}_{2}$ and $\mathrm{H}_{2} \mathrm{O}_{2}$ with organic compounds at elevated temperatures may be explo- sive!) The reaction solutions were analyzed by using GC after the addition of nitromethane as a standard compound. A LKhM-80-6 instrument was used (columns $2 \mathrm{~m}$ with $5 \%$ Carbowax 1500 on $0.25-0.315 \mathrm{~mm}$ Inerton AW-HMDS; carrier gas Ar) to measure concentrations of cyclohexanol and cyclohexanone. Samples of reaction solutions were in some cases analyzed twice: before and after their treatment with $\mathrm{PPh}_{3}$. This method (an excess of solid $\mathrm{PPh}_{3}$ is added to the samples 10-15 min before the GC analysis) proposed previously by one of us $^{[27]}$ allows us to detect alkyl hydroperoxides and to measure also the real concentrations of all three products (alkyl hydroperoxide, alcohol, and aldehyde or ketone) present in the reaction solution because alkyl hydroperoxides are usually decomposed in the gas chromatograph to produce mainly the corresponding alcohol and ketone. It is necessary to emphasize that the $\mathrm{PPh}_{3}$ is added mainly to compare intensities of cyclohexanol and cyclohexanone peaks and not to reduce the remaining $\mathrm{H}_{2} \mathrm{O}_{2}$. The comparison gives us the real concentration of cyclohexyl hydroperoxide in the reaction mixture. In our kinetic studies described below, to determine the initial reaction rate $W_{0}$ we measured the concentrations of cyclohexanone and cyclohexanol only after the reduction of the reaction mixture with $\mathrm{PPh}_{3}$, which gives the precise concentration of a sum of the oxygenates. Blank experiments with cyclohexane showed that in the absence of 1 and $\mathbf{4}$ no products were formed.

\section{Amides synthesis}

General considerations: All reagents were purchased from Aldrich Chemical Co., Fluka, and Alfa Aesar and used without further purification. Analyses were performed at the 'Plateforme Technologique Laboratoire de Mesures Physiques' (IBMM, Université de Montpellier). ${ }^{1} \mathrm{H}$ NMR spectra were recorded by using a Bruker Avance DPX $300 \mathrm{MHz}$ spectrometer. Chemical shifts are reported in ppm and referenced to the solvent peak $\left(\mathrm{CDCl}_{3}\right.$ at $\left.7.26 \mathrm{ppm}\right)$. Data are reported as $\mathrm{s}=$ singlet, $\mathrm{d}=$ doublet, $\mathrm{t}=$ triplet, $\mathrm{q}=$ quadruplet, $\mathrm{qt}=$ quintuplet, sept $=$ septuplet, and $\mathrm{m}=$ multiplet; coupling constants in $\mathrm{Hz}$; integration. ${ }^{13} \mathrm{CNMR}$ spectra were recorded by using a Bruker Avance AM $126 \mathrm{MHz}$ spectrometer. Chemical shifts are reported in ppm and referenced to the solvent peak $\left(\mathrm{CDCl}_{3}\right.$ at $\delta=$ $77.16 \mathrm{ppm})$.

General procedure: Into a sealed tube were added successively amine hydrochloride $(0,5 \mathrm{mmol}), \mathrm{CaCO}_{3}(50.1 \mathrm{mg}, 0.5 \mathrm{mmol})$, $\mathrm{CH}_{3} \mathrm{CN}(1 \mathrm{~mL}), 1$ (20 $\mu \mathrm{L}$ of a solution of $3.0 \mathrm{mg}$ of 1 in $2 \mathrm{~mL}$ of $\left.\mathrm{CH}_{3} \mathrm{CN}\right)$ or $3\left(20 \mu \mathrm{L}\right.$ of a solution of $1.8 \mathrm{mg}$ of 3 in $2 \mathrm{~mL}$ of $\left.\mathrm{CH}_{3} \mathrm{CN}\right)$, benzylic alcohol $(105 \mu \mathrm{L}, 1.0 \mathrm{mmol})$, and TBHP $(5.5 \mathrm{M}$ in nonane, $225 \mu \mathrm{L}, 1.25 \mathrm{mmol})$. The mixture was stirred at $80^{\circ} \mathrm{C}$ for $2 \mathrm{~h}$, and TBHP ( $5.5 \mathrm{M}$ in nonane, $225 \mu \mathrm{L}, 1.25 \mathrm{mmol}$ ) was added again to the mixture. After $22 \mathrm{~h}$ at $80^{\circ} \mathrm{C}$, the mixture was cooled to RT, and $1 \mathrm{~N}$ $\mathrm{HCl}$ and $\mathrm{AcOEt}$ were added. The mixture was extracted twice with AcOEt, and the combined organic phases were washed with a saturated solution of $\mathrm{NaHCO}_{3}$ and brine and concentrated under reduced pressure. To remove the excess of benzylic alcohol, $\mathrm{H}_{2} \mathrm{O}$ $(80 \mathrm{~mL})$ was added and evaporated under reduced pressure. The crude product was then purified using silica gel chromatography using gradients of cyclohexane/AcOEt to yield the pure compounds.

\section{Acknowledgements}

This work has been supported by the Russian Foundation for Basic Research (Grants 16-03-00254; 16-53-150008; 16-29- 
05180), by the "RUDN University Program 5-100", the French Embassy in Moscow, the University of Montpellier, CNRS (Programme de Recherche Conjoint). Synchrotron single-crystal diffraction measurements were performed at the unique scientific facility Kurchatov Synchrotron Radiation Source supported by the Ministry of Education and Science of the Russian Federation (project code RFMEFI61917X0007).

\section{Conflict of interest}

The authors declare no conflict of interest.

Keywords: amides · cage compounds · copper • oxidation synthesis design

[1] a) M. D. Ward, Chem. Commun. 2009, 448744499; b) J. J. Perry IV, J. A. Perman, M. J. Zaworotko, Chem. Soc. Rev. 2009, 38, 1400-1417; c) H. Amouri, C. Desmarets, J. Moussa, Chem. Rev. 2012, 112, 2015-2041 d) P. Jin, S. J. Dalgarno, J. L. Atwood, Coord. Chem. Rev. 2010, 254, 1760 1768; e) M. M. J. Smulders, I. A. Riddell, C. Browne, J. R. Nitschke, Chem. Soc. Rev. 2013, 42, 1728 1754; f) T. Nakamura, H. Ube, M. Shionoya, Chem. Lett. 2013, 42, 328 (334; g) H. Li, Z.-J. Yao, D. Liu, G.-X. Jin, Coord. Chem. Rev. 2015, 293/294, 139-157, h) L. Chen, Q. Chen, M. Wu, F. Jiang, M. Hong, Acc. Chem. Res. 2015, 48, 201-210

[2] R. Murugavel, A. Voigt, M. G. Walawalkar, H. W. Roesky, Chem. Rev. 1996, 96, 2205-2236.

[3] F. J. Feher, D. A. Newman, J. F. Walzer, T. Am. Chem. Soc. 1989, 111 174171748

[4] a) E. A. Quadrelli, J.-M. Basset, Coord. Chem. Rev. 2010, 254, 707/728; b) A. J. Ward, A. F. Masters, T. Maschmeyer, Adv. Silicon Sci. 2011, 3, 135 166.

[5] a) M. M. Levitsky, A. I. Yalymov, A. N. Kulakova, A.A. Petrov, A. N. Bilyachenko, T. Mol. Catal. A 2017, 426, 297-304; b) M. M. Levitsky, A. N. Bilyachenko, G. B. Shul'pin, J. Organomet. Chem. 2017, https://doi.org/ 10.1016/j.jorganchem.2017.05.007

[6] a) A. N. Bilyachenko, A. I. Yalymov, A. A. Korlyukov, J. Long, J. Larionova, Y. Guari, Y. V. Zubavichus, A. L. Trigub, E. S. Shubina, I. L. Eremenko, N. N. Efimov, M. M. Levitsky, Chem. Eur. J. 2015, 21, 18563]18565; b) A. N. Bilyachenko, A. I. Yalymov, A. A. Korlyukov, J. Long, J. Larionova, Y. Guari, A. V. Vologzhanina, M. A. Es'kova, E. S. Shubina, M. M. Levitsky, Dalton trans. 2016, 45, 7320 327 c) A. N. Bilyachenko, M. M. Levitsky, A. I. Yalymov, A. A. Korlyukov, A. V. Vologzhanina, Yu.N. Kozlov, L. S. Shul'pina D. N. Nesterov, A. J. L. Pombeiro, F. Lamaty, X. Bantreil, A. Fetre, D. Liu, J. Martinez, J. Long, J. Larionova, Y. Guari, A. L. Trigub, Y. V. Zubavichus, I. E. Golub, O. A. Filippov, E. S. Shubina, G. B. Shul'pin, RSC AdV. 2016, 6, 4816548180; d) A. N. Bilyachenko, A. I. Yalymov, M. M. Levitsky, A. A Korlyukov, M. A. Eskova, J. Long, J. Larionova, Y. Guari, L. S. Shul'pina, N. S. Ikonnikov, A. L. Trigub, Y. V. Zubavichus, I. E. Golub, E. S. Shubina, G. B. Shul'pin, Dalton Trans. 2016, 45, 13663H13666; e) A. N. Bilyachenko, A. Yalymov, M. Dronova, A. A. Korlyukov, A. V. Vologzhanina, M. A Es'kova, J. Long, J. Larionova, Y. Guari, P. V. Dorovatovskii, E. S. Shubina, M. M. Levitsky, Inorg. Chem. 2017, https://doi.org/10.1021/acs.inorgchem.7b01436

[7] E. V. Beletskiy, Y. Wu, M. C. Kung, H. H. Kung, Organometallics 2016, 35, 301-B02

[8] S. Sakugawa, K. Wada, M. Inoue, T. Catal. 2010, 275, 280-28724

[9] a) F. T. Edelmann, Silicon Chemistry: From the Atom to Extended Systems (P. Jutzi, U. Schubert, Eds.), Wiley, 2007, 383-394 and references cited therein; b) E. V. Beletskiy, Z. Shen, M. V. Riofski, X. Hou, J. R. Gallagher, J. T. Miller, Y. Wu, H. H. Kung, M. C. Kung, Chem. Commun. 2014, 50, 15699 ; c) S. Ehle, V. Lorenz, P. Liebing, L. Hilfert, F. T. Edelmann, Enorg. Chem. Commun. 2016, 74, 82 -185; d) S. Gießmann, V. Lorenz, P. Liebing, L. Hilfert, A. Fischer, F. T. Edelmann, Dalton Trans. 2017, 46, 2415 F2419

[10] M. Hirotsu, S. Taruno, T. Yoshimura, K. Ueno, M. Unno, H. Matsumoto, Chem. Lett. 2005, 34, 1542, 1543.
[11] a) H. W. Roesky, G. Anantharaman, V. Chandrasekhar, V. Jancik, S. Singh Chem. Eur. J. 2004, 10, 4106-14114 and references cited therein; b) M. M Levitsky, A. N. Bilyachenko, Coord. Chem. Rev. 2016, 306, 235-R69 and references cited therein; c) V. Chandrasekhar, R. Thirumoorthi, norg. Chem. 2009, 48, 6236-6241 d) M. S. R. Prabhu, U. Ugandhar, V. Baskar, Dalton Trans. 2016, 45, 6963-6967; e) K. S. Lokare, N. Frank, B. BraunCula, I. Goikoetxea, J. Sauer, C. Limberg, Angew. Chem. Int. Ed. 2016, 55, 12325 12329; Angew. Chem. 2016, 128, 12513 112517.

[12] N. V. Sergienko, A. A. Korlyukov, D. E. Arkhipov, V. V. Novikov, M. A. Eskova, B. G. Zavin, Mendeleev Commun. 2016, 26, 344-B46.

[13] A. A. Korlyukov, A. V. Vologzhanina, M. I. Buzin, N. V. Sergienko, B. G. Zavin, A. M. Muzafarov, Cryst. Growth Des. 2016, 16, 1968-1977

[14] a) H. C. L. Abbenhuis, A. D. Burrows, H. Kooijman, M. Lutz, M. T. Palmer, R. A. van Santen, A. L. Spek, Chem. Commun. 1998, 2627-2628; b) F. Liu, K. D. John, B. L. Scott, R. T. Baker, K. C. Ott, W. Tumas, Angew. Chem. Int. Ed. 2000, 39, 3127-3130; Angew. Chem. 2000, 112, 3257-3260.

[15] A. Lee, J. Xiao, F. J. Feher, Wacromolecules 2005, 38, 438 444 ,

[16] G. Anantharaman, H. W. Roesky, H.-G. Schmidt, M. Noltemeyer, J. Pinkas, norg. Chem. 2003, 42, 970-973.

[17] U. N. Nehete, G. Anantharaman, V. Chandrasekhar, R. Murugavel, M. G. Walawalkar, H. W. Roesky, D. Vidovic, J. Magull, K. Samwer, B. Sass, Angew. Chem. Int. Ed. 2004, 43, 3832-3835; Angew. Chem. 2004, 116, उ920-3923.

[18] G. L. Abbati, A. Cornia, A. Caneschi, A. C. Fabretti, C. Mortalò, norg. Chem. 2004, 43, 4540-4542

[19] L. Zherlitsyna, N. Auner, M. Bolte, Acta Crystallogr. Sect. C 2006, 62, m199-m200

[20] A. N. Bilyachenko, A. N. Kulakova, M. M. Levitsky, A. A. Petrov, A. A. Kor lyukov, L. S. Shul'pina, V. N. Khrustalev, P. V. Dorovatovskii, A. V. Vologzhanina, U. S. Tsareva, I. E. Golub, E. S. Gulyaeva, E. S. Shubina, G. B. Shul'pin, norg. Chem. 2017, 56, 4093-4103.

[21] A. N. Bilyachenko, M. S. Dronova, A. A. Korlyukov, M. M. Levitsky, M.Yu. Antipin, B. G. Zavin, Russ. Chem. Bull. 2011, 60, 1762 1765.

[22] A. N. Bilyachenko, M. S. Dronova, A. I. Yalymov, F. Lamaty, X. Bantreil, J. Martinez, C. Bizet, L. S. Shul'pina, A. A. Korlyukov, D. E. Arkhipov, M. M. Levitsky, E. S. Shubina, A. M. Kirillov, G. B. Shul'pin, Chem. Eur. J. 2015, 21, 8758-8770

[23] G. E. Kostakis, V. A. Blatov, D. M. Proserpio, Dalton Trans. 2012, 47, $4634-4640$

[24] a) Y. Shiota, K. Yoshizawa, norg. Chem. 2009, 48, 838-1845; b) M. Srnec U. Ryde, L. Rulíšek, Faraday Discuss. 2011, 148, 41-53; c) L. Rulíšek, U. Ryde, Coord. Chem. Rev. 2013, 257, 445-458; d) E. I. Solomon, D. E. Heppner, E. M. Johnston, J.W. Ginsbach, J. Cirera, M. Qayyum, M. T. Kieber-Emmons, C. H. Kjaergaard, R. G. Hadt, L. Tian, Chem. Rev. 2014, 174, 3659-3853.

[25] a) A. M. Sakharov, I. P. Skibida, T. Mol. Catal. 1988, 48, 157/1744; b) I. E. Markó, A. Gautier, R. Dumeunier, K. Doda, F. Philippart, S. M. Brown, C. J. Urch, Angew. Chem. Int. Ed. 2004, 43, 1588 1591; Angew. Chem. 2004, 176, 1614-1617 c) Q. Zhu, Y. Lian, S. Thyagarajan, S. E. Rokita, K. D. Karlin, N. V. Blough, J. Am. Chem. Soc. 2008, 130, 6304-6305; d) C. Würtele, O. Sander, V. Lutz, T. Waitz, F. Tuczek, S. Schindler, J. Am. Chem. Soc 2009, 131, 7544-7545; e) M. N. Kopylovich, A. C. C. Nunes, K. T. Mahmudov, M. Haukka, T. C. O. Mac Leod, L. M. D. R. S. Martins, M. L. Kuznetsov, A. J. L. Pombeiro, Dalton Trans. 2011, 40, 2822_E2836; f) A. L. Maksimov, Y. S. Kardasheva, V. V. Predeina, M. V. Kluev, D. N. Ramazanov, M. Y. Talanova, E. A. Karkhanov, Petrol. Chem. 2012, 52, 318-326; g) A. M. Kirillov, M. V. Kirillova, A. J. L. Pombeiro, Coord. Chem. Rev. 2012, 256, 2741 2759; h) Z. Ma, L. Wei, C. B. A. Alegria, L. M. D. R.S. Martins, M. F. C. G. da Silva, A. J. L. Pombeiro, Dalton Trans. 2014, 43, 4048-4058; i) J. T. Tinge in Liquid Phase Aerobic Oxidation Catalysis: Industrial Applications and Academic Perspectives (Eds.: S. S. Stahl, P. L. Alsters) Wiley-VCH, 2016.

[26] a) A. N. Bilyachenko, M. S. Dronova, A. I. Yalymov, A. A. Korlyukov, L. S. Shul'pina, D. E. Arkhipov, E. S. Shubina, M. M. Levitsky, A. D. Kirilin, G. B. Shul'pin, Eur. J. Inorg. Chem. 2013, 5240E5246; b) M. S. Dronova, A. N. Bilyachenko, A. I. Yalymov, Y. N. Kozlov, L. S. Shul'pina, A. A. Korlyukov, D. E. Arkhipov, M. M. Levitsky, E. S. Shubina, G. B. Shul'pin, Dalton Trans. 2014, 43, 872-1882; c) M. M. Vinogradov, Y. N. Kozlov, A. N. Bilyachenko, D. S. Nesterov, L. S. Shul'pina, Y. V. Zubavichus, A. J. L. Pombeiro, M. M Levitsky, A. I. Yalymov, G. B. Shul'pin, New J. Chem. 2015, 39, 187/199

[27] a) G. B. Shul'pin, J. Mol. Catal. A 2002, 189, 39-66; b) G. B. Shul'pin, Mini-Rev. Org. Chem. 2009, 6, 95-104; c) G. B. Shul'pin, Y. N. Kozlov, L. S. 
Shul'pina, A. R. Kudinov, D. Mandelli, Inorg. Chem. 2009, 48, $10480-$ 10482 ; d) G. B. Shul'pin, Y. N. Kozlov, L. S. Shul'pina, P. V. Petrovskiy, Appl. Organometal. Chem. 2010, 24, 464-472; e) G. B. Shul'pin, Org. Biomol. Chem. 2010, 8, 4217-4228; f) G. B. Shul'pin, Dalton Trans. 2013, 42, $12794-12818$; g) G. B. Shul'pin, Catalysts 2016, 6, 50.

[28] A. I. Yalymov, A. N. Bilyachenko, M. M. Levitsky, A. A. Korlyukov, V. N. Khrustalev, L. S. Shul'pina, P. V. Dorovatovskii, M. A. Es'kova, F. Lamaty, X Bantreil, B. Villemejeanne, J. Martinez, E. S. Shubina, Y. N. Kozlov, G. B. Shul'pin, Catalysts 2017, 7, 101.

[29] a) X. Bantreil, C. Fleith, J. Martinez, F. Lamaty, ChemCatChem 2012, 1922 1925; b) K. Azizi, M. Karimi, F. Nikbakht, A. Heydari, Appl. Catal. A 2014, 482, 336- 343
[30] a) S. C. Ghosh, J. S. Y. Ngiam, A. M. Seayad, D. T. Tuan, C. W. Johannes, A. Chen, etrahedron Lett. 2013, 54, 4922 44925; b) S. Gaspa, A. Porcheddu, L. De Luca, Org. Biomol. Chem. 2013, 11, 3803/B807 c) X. Bantreil, N. Kanfar, N. Gehin, E. Golliard, P. Ohlmann, J. Martinez, F. Lamaty, letrahearon 2014, 70, 5093-5099.

[31] X.-F. Wu, M. Sharif, A. Pews-Davtyan, P. Langer, K. Ayub, M. Beller, Eur. J. Org. Chem. 2013, 2783-2787 